\title{
Cardiac surgery comes first!
}

\author{
Stephen D. Waterford, MD, and Marc R. Moon, MD
}

\footnotetext{
From the Division of Cardiothoracic Surgery, Department of Surgery, Washington University in St Louis, St Louis, Mo.

Disclosures: Authors have nothing to disclose with regard to commercial support.

Received for publication Jan 30, 2018; accepted for publication Jan 31, 2018

Address for reprints: Marc R. Moon, MD, John M. Shoenberg Chair in Cardiovascular Disease, Division of

Cardiothoracic Surgery, Washington University School of Medicine, 4566 Scott Ave, Box 8234, St. Louis,

MO 63110 (E-mail: moonm@wustl.edu).

J Thorac Cardiovasc Surg 2018;156:3-4

$0022-5223 / \$ 36.00$

Copyright (c) 2018 by The American Association for Thoracic Surgery

https://doi.org/10.1016/j.jtcvs.2018.01.067
}

We read with great interest the article by Chiu and colleagues ${ }^{1}$ from Stanford University on the important topic of type A dissection and malperfusion. Although their study confirms what we believe-that prompt surgery for type A dissection is warranted-there are some surprising findings. First, patients with malperfusion did not have higher mortality than those without malperfusion. This finding also seems to have surprised the authors themselves, because it contravenes traditional teaching on malperfusion, including our own series, in which mortality was 3-fold higher with malperfusion. ${ }^{2}$ Second, and less suprising, is the impressively low rate of subsequent intervention on vessels that were malperfused before type A repair-only $12.5 \%$ in this series, and that at 10 years. Third is the overwhelming proportion of patients who were transferred to Stanford from a referring institution for their repair: 93.1\%. This confirms what we also believe-that patients with type A dissection, in the absence of hemodynamic instability, should be transferred to experienced aortic centers, as articles from Stanford and elsewhere have emphasized. ${ }^{3-5}$ In support of this, the authors performed a skin incision within 24 hours of symptom onset in $79.3 \%$ of their patients.

We would add one caveat on malperfusion that we believe to be of clinical utility, relating to risk stratification among patients with malperfusion. Not all patients with malperfusion are the same, although they have tended to be grouped together in the literature. In our own institutional experience of 282 patients with type A dissection, we found that malperfusion plus a base excess of -10 or worse is rarely survivable, and that malperfusion with a base excess between -5 and -10 is associated with a marked elevation in mortality (Table 1 ). ${ }^{2}$ In fact, in our series, malperfusion and a severe base deficit were worse than receiving cardiopulmonary resuscitation at the time of operation. It appears that base excess has a remarkable predictive ability across patient populations. In the trauma substantial.

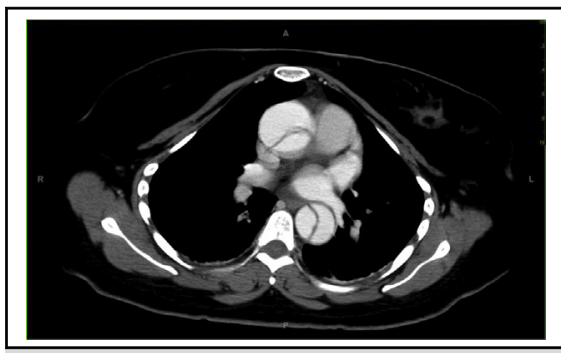

Malperfusion with DeBakey I dissection will often resolve following ascending repair.

Central Message

Immediate operation for type A dissection remains warranted in the current endovascular era, given the risk for immediate lifethreatening complications arising from the ascending aorta, even in the presence of branch vessel malperfusion.

See Article page 18 .

literature, for example, we find that mortality is often nearly perfectly and linearly related to base deficit. ${ }^{6}$ The value of the simple and time-honored base deficit remains

Also worth noting in this series is that the low rate of intervention on malperfused branch vessels after type $\mathrm{A}$ repair implies that most branch vessel obstructions are dynamic, and are relieved by restoration of true lumen flow by type A repair. Static obstructions that type A repair would not address, ipso facto, must be relatively rare, if the branch vessel is not subsequently intervened on. It is such series that teach us about the physiology of dissections and confirm what we have favored-that malperfusion arises more from dynamic obstruction than static

TABLE 1. Mortality in patients with base deficit -5 or greater $(n=66)$

\begin{tabular}{ccc}
\hline Variable & $\begin{array}{c}\text { Malperfusion } \\
(\mathbf{N}=\mathbf{3 3})\end{array}$ & $\begin{array}{c}\text { No malperfusion } \\
(\mathbf{N}=\mathbf{3 3})\end{array}$ \\
\hline Base deficit -5 to $-10(\mathrm{n}=42)$ & 21 & 21 \\
Operative death $(\mathrm{n}=11)$ & $10(10 / 21 ; 48 \%)$ & $1(1 / 21 ; 5 \%)$ \\
Base deficit $\geq-10(\mathrm{n}=24)$ & 12 & 12 \\
Operative death $(\mathrm{n}=11)$ & $11(11 / 12 ; 92 \%)$ & $0(0 / 12 ; 0 \%)$ \\
\hline
\end{tabular}

When combined with malperfusion, patients at extreme risk can be identified. Reprinted from Lawton et al. ${ }^{2}$ 
obstruction. This provides the physiological basis for immediate type A repair.

\section{References}

1. Peter Chiu, Sarah Tsou, Goldstone Andrew B, Mikaela Louie, Joseph Woo Y, Fischbein Michael P. Immediate operation for acute type A aortic dissection complicated by visceral or peripheral malperfusion. J Thorac Cardiovasc Surg. 2018;156:18-24.

2. Lawton JS, Moon MR, Liu J, Koerner DJ, Kulshrestha K, Damiano RJ, et al. The profound impact of combined severe acidosis and malperfusion on operative mortality in the surgical treatment of type A aortic dissection. $J$ Thorac Cardiovasc Surg. 2018;155:897-904.

3. Miller DC. Another meiosis in the specialty of cardiovascular and thoracic surgery: birth of the purebred thoracic aortic surgeon? J Am Coll Cardiol. 2014;63:1804-6.

4. Miller DC. How I would like my acute ascending aortic dissection to be treated. Presented at: 95th Annual Meeting of The American Association for Thoracic Surgery; April 25, 2015; Seattle, WA.

5. Andersen ND, Ganapathi AM, Hanna JM, Williams JB, Gaca JG, Hughes GC. Outcomes of acute type A dissection repair before and after implementation of a multidisciplinary thoracic aortic surgery program. J Am Coll Cardiol. 2014;63:1796-803.

6. Siegal JH, Rivkind AI, Dalal S, Goodarzi S. Early physiologic predictors of injury severity and death in blunt multiple trauma. Arch Surg. 1990;125:498-508.

Access to The Journal of Thoracic and Cardiovascular Surgery Online is reserved for print subscribers!

Full-text access to The Journal of Thoracic and Cardiovascular Surgery Online is available for all print subscribers. To activate your individual online subscription, please visit The Journal of Thoracic and Cardiovascular Surgery Online, point your browser to http://www.mosby.com/jtcvs, follow the prompts to activate your online access, and follow the instructions. To activate your account, you will need your subscriber account number, which you can find on your mailing label (note: the number of digits in your subscriber account number varies from 6 to 10). See the example below in which the subscriber account number has been circled:

\section{Sample mailing label}

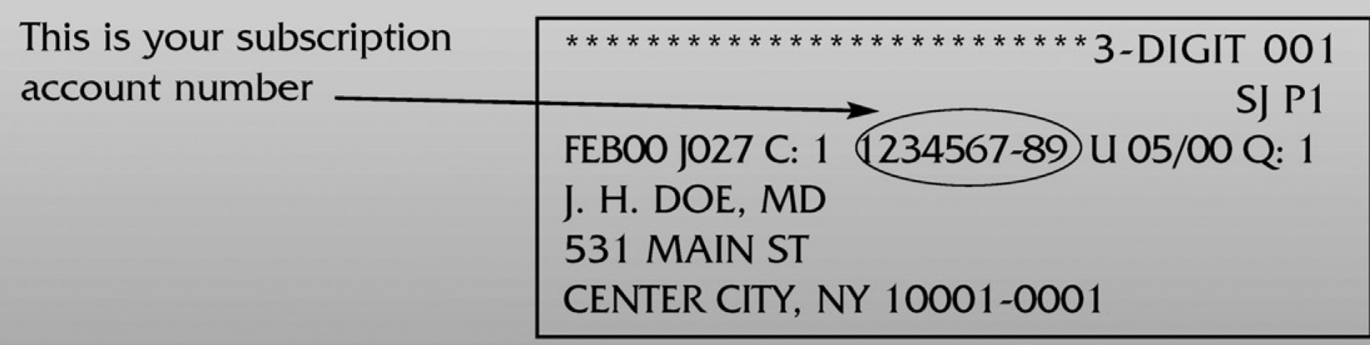

Personal subscriptions to The Journal of Thoracic and Cardiovascular Surgery Online are for individual use only and may not be transferred. Use of The Journal of Thoracic and Cardiovascular Surgery Online is subject to agreement to the terms and conditions as indicated online. 